\title{
Kajian kerusakan lingkungan pada tambang intan berbasis pertambangan rakyat di Kecamatan Cempaka, Kalimantan Selatan
}

\author{
Lely Adriani Nasution ${ }^{1 *}$, Suratman $^{1,2}$ dan Sudrajat ${ }^{1,2}$
}

${ }^{1}$ Program Studi Magister Ilmu Lingkungan, Sekolah Pascasarjana Universitas Gadjah Mada, Yogyakarta, Indonesia

${ }^{2}$ Departemen Ilmu Lingkungan, Fakultas Geografi, Universitas Gadjah Mada, Yogyakarta, Indonesia

Koresponden Email: nasutionlely@gmail.com

Direvisi: 2021-01-17 Diterima: 2021-03-03

(C)2021 Fakultas Geografi UGM dan Ikatan Geograf Indonesia (IGI)

\begin{abstract}
Abstrak. Penambangan intan di Kecamatan Cempaka telah ada sejak dulu dan dikelola langsung oleh masyarakat serta tergolong sebagai tambang rakyat yang berskala kecil. Keberadaan tambang intan memunculkan permasalahan pada lingkungan berupa kerusakan. Kerusakan yang ditimbulkan mencakup seluruh aspek seperti abiotik, biotik dan kultural. Untuk itu perlu dilakukan suatu kajian terkait bagaimana kerusakan yang ditimbulkan dari kegiatan tersebut. Tujuan pada penelitian ini berupa, (1) mengidentifikasi jenis kerusakan lingkungan akibat kegiatan pertambangan intan, (2) menganalisis tingkat kerusakan lingkungannya, (3) merumuskan strategi pengelolaan yang sesuai untuk kerusakan lingkungan akibat pertambangan intan tersebut. Metode yang digunakan dalam penelitian merupakan metode gabungan antara kuantitatif berupa skoring dan perhitungan kelas interval serta kualitatif berupa wawancara mendalam, yang mengacu pada kriteria dari Buku I Kerusakan Lahan Akses Terbuka Akibat Tambang Rakyat oleh Kementrian Lingkungan Hidup dan Kehutanan (KLHK) tahun 2015. Hasil penelitian menunjukkan bahwa identifikasi jenis kerusakan lingkungan memiliki kesesuaian dengan parameter yang ada pada ketentuan KLHK tahun 2015. Analisis tingkat kerusakan menunjukkan bahwa titik pengamatan 4 di Kelurahan Sungai Tiung menjadi titik dengan tingkat kerusakan yang berat. Perumusan strategi pengelolaan menunjukkan bahwa pengalihfungsian lokasi pertambangan menjadi tujuan wisata adalah upaya pengelolaan yang paling tepat.
\end{abstract}

Kata kunci: tambang rakyat, tambang intan, kerusakan lingkungan, strategi pengelolaan

\begin{abstract}
Diamond mining in Cempaka Subdistrict existed for a long time ago and was handled by community groups and included as small-scale artisanal mining. The existence of diamond mining causes a problem to the environment like environmental damage. The damage caused covers all aspects such as abiotic, biotic, and cultural. Thus, it needs to carry out a study related to how these activities cause the damage. The purposes of the research are, (1) Identify the types of environmental damage, (2) analyze the level of environmental damage, (3) formulate the appropriate management strategies for environmental damage caused by diamond mining. The research method uses mix method between quantitative like scoring and calculation an interval class, and qualitative, with an in-depth interview, which references Book I Open Access to Land Damage due to Artisanal Mining by the Ministry of Environmental and Forestry 2015. The results showed that identifying the environmental damage type was in accordance with the parameters in 2015 of KLHK references. Analyze an environmental damage level shows the heavy damage level found in observation point 4 in Sungai Tiung. Formulation of a management strategy shows that mining sites' conversion to tourism destinations is the most appropriate.
\end{abstract}

Keywords: community mining, diamond mining, environmental damage, management strategy

\section{PENDAHULUAN}

Provinsi Kalimantan Selatan memiliki berbagai potensi sumberdaya alam yang terbagi menjadi bahan galian energi, bahan galian logam dan bahan galian industri yang salah satunya adalah intan dan tegolong dalam bahan galian industri yang hanya terdapat di Kota Banjarbaru (Dinas Penanaman Modal dan Pelayanan Terpadu Satu Pintu, 2018). Intan terbentuk bersamaan dengan pembekuan batuan ultrabasa misal periodit dan kimberlit. Kristalisasi intan pada kimberlite pipe terbentuk pada kedalaman 60 mil (kurang lebih $95 \mathrm{~km}$ ) atau lebih dalam di bawah permukaan bumi dan pada temperatur $1.500-2.000^{\circ} \mathrm{C}$ dan mempunyai hablur dengan sistem kubus, umumnya berwarna bening tetapi kadang - kadang berwarna kebiruan, kehijauan, kemerahan atau kuning, berat jenis 3,52 dengan kilap adamantin dengan garis tengah atom $1,54^{\circ} \mathrm{A}$, dengan tingkat kekerasan pada skala Mohs mencapai angka 10 atau 8.000-8.500 knop (Sukandarrumidi, 1998).

Potensi intan yang ada di Kalimantan Selatan terbentuk karena dilatarbelakangi oleh berbagai proses. Spekulasi mengenai proses pembentukan intan di Pulau Kalimantan, termasuk Provinsi Kalimantan Selatan dibagi menjadi empat berdasarkan pemodelan geologi. Spekulasi pertama terjadi 
karena intan berasosiasi dengan batuan ultramafic yang hancur sebagai ophiolite. Kedua, intan terbentuk karena proses yang terdapat pada zona subduksi dan terbawa ke permukaan melalui proses yang tidak termasuk dalam kimberlite pipe atau lamproite. Ketiga, intan di Kalimantan telah tertransportasi dalam jarak yang sangat jauh oleh sistem -sistem perairan sungai besar yang terdrainase dari Subimasu Terrane sebelum Kalimantan terpisah dengan Indocina. Keempat, intan terbentuk melalui sungai besar dari bagian barat laut Australia dan mengalami transportasi sebelum bagian Kalimantan terpisah pada kurun waktu Jurra (White et al., 2016).

As'ad menyatakan (dalam Azkia, 2018) penambangan intan yang ada di Kota Banjarbaru, secara lebih spesifik terletak di Kecamatan Cempaka dan tergolong dalam penambangan skala kecil karena merupakan tambang rakyat. Pertambangan rakyat adalah jenis pertambangan tertua yang pernah ada dan biasanya umum ditemukan pada daerah dengan karakteristik masyarakat yang miskin (Owusu et al, 2019). Terminologi tambang rakyat sebagai tambang berskala kecil didapat setelah adanya Keputusan Bersama Menteri Pertambangan dan Energi, Menteri Dalam Negeri dan Menteri Koperasi, Pengusaha Kecil dan Menengah Nomor: 2002.K/20/MPE/1998-Nomor: 151A Tahun 1998Nomor: 23/SKB/M/XII/1998; yakni suatu usaha pertambangan umum atas galian golongan $\mathrm{A}, \mathrm{B}$ dan $\mathrm{C}$ yang dilakukan oleh penguasaha kecil atau koperasi setempat.

Berdasarkan surat keputusan bersama tersebut, tambang intan yang ada di Kecamatan Cempaka termasuk dalam tambang rakyat dengan kategori status tanpa izin usaha dan jenisnya berupa penambangan setempat tanpa izin dengan jumlah pekerja tidak lebih dari 5.000 orang. Pertambangan intan di Kecamatan Cempaka dulunya bersifat tradisional, namun seiring berjalannya waktu terjadi peralihan dalam penggunaan alat, sehingga penambangan intan yang ada saat ini menjadi bersifat semi-mekanik. Penambangan rakyat yang minim kemampuan dalam pengoperasian alat menggunakan mesin saat menambang mampu menyebabkan memberikan dampak pada lingkungan (USAID, 2017). Kerusakan pada lingkungan tersebut akan semakin buruk apabila dari waktu ke waktu tidak dilakukan penanganan maupun perbaikan (Australian Government, 2016). Penelitian ini dilakukan untuk mengkaji kerusakan lingkungan yang terjadi mulai dari mengidentifikasi, menganalisis, sampai pada merumuskan strategi pengelolaan sebagai upaya penanganan berkelanjutan yang sesuai.

\section{METODE PENELITIAN}

Penelitian dilakukan dengan menggunakan metode mix method yakni kombinasi antara kuantitaif dan kualitatif. Penggunaan metode kuantitatif dipilih untuk melakukan perhitungan yang dimulai dari skoring untuk tiap parameter di tiap aspek, kemudian perhitungan untuk menentukan kelas interval tingkat kerusakan lingkungannya. Metode kualitatif digunakan untuk menganalisis kajian kultural melalui in depth interview dengan informan yang telah ditentukan sebelumnya secara purposive. Teknik wawancara yang digunakan dalam pengumpulan data pada penelitian ini merupakan wawancara semi-terstruktur yakni dengan cara melakukan wawancara berdasarkan pertanyaan yang sudah terstruktur untuk kemudian satu persatu lebih diperdalam untuk memperoleh keterangan lebih lanjut (Arikunto, 2013).
Identifikasi jenis kerusakan lingkungan

Identifikasi jenis kerusakan lingkungan dibagi menjadi tiga aspek yakni abiotik, biotik dan kultural dengan variabel atau parameter yang telah disesuaikan dengan kondisi di lapangan. Aspek abiotik mewakili kondisi fisik, aspek biotik mewakili kondisi hewan dan tumbuhan dan aspek kultural merepresentasikan kondisi sosial ekonomi masyarakat. Parameter yang digunakan dalam mengidentifikasi jenis kerusakan lingkungan menggunakan acuan dari Buku I Kerusakan Lahan Akses Terbuka Akibat Tambang Rakyat yang ditetapkan oleh Kementrian Lingkungan Hidup dan Kehutanan tahun 2015 dan dimodifikasi sebagian untuk menyesuaikan kondisi yang ada di lapangan. Pengharkatan dilakukan dengan memberikan skor 1, 2 dan 3 yang artinya "tidak rusak" untuk skor 1, "sedang” untuk skor 2 dan "tidak rusak" untuk skor 3. Proses pengharkatan dilakukan oleh penulis dan informan dengan mengamati tiap parameter untuk menghindari subjektifitas jawaban. Parameter pada tiap aspek yang terdapat dalam penelitian ini disajikan pada Tabel 1.

\section{Analisis tingkat kerusakan lingkungan}

Analisis tingkat kerusakan lingkungan dilakukan melalui perhitungan hasil pengharkatan/skoring dengan cara menjumlahkan seluruh hasil skor pada semua aspek di masing-masing titik pengamatan. Setelah total diperoleh, analisis tingkat kerusakan dilanjutkan dengan menghitung kelas interval agar dapat diketahui kategori dalam tingkatannya. Tingkatan yang ditunjukkan dari kelas interval terbagi menjadi tiga, yakni "Rusak Ringan”, "Rusak Sedang" dan "Rusak Berat". Deskripsi yang ditunjukkan dari kelas interval berbeda seperti deskripsi pada saat pengharkatan. Pada kelas interval penggunaan deskripsi lebih mengacu pada tingkat sehingga redaksinya lebih menyatakan pada level rusaknya. Rumus yang digunakan untuk perhitungan kelas interval akan disajikan pada persamaan/rumus 1

$$
\mathrm{i}=\frac{\sum \mathrm{a}-\Sigma \mathrm{b}}{\mathrm{n}}
$$

Keterangan:

$$
\text { (Hadi dalam Hasnia, 2018) }
$$

i $\quad=$ Lebar kelas interval

$\sum \mathrm{a}=$ Jumlah harkat tertinggi

$\sum \mathrm{b} \quad=$ Jumlah harkat terendah

$\mathrm{n} \quad=$ Jumlah kelas

\section{Perumusan Strategi Pengelolaan Lingkungan}

Perumusan strategi pengelolaan lingkungan berkonsep pada tatanan payung hukum yang tinggi sampai pada payung hukum regional. Konsep payung hukum ini dilandasi dari Undang-Undang Nomor 32 tahun 2009 tentang Perlindungan dan Pengelolaan Lingkungan Hidup, Peraturan Menteri Energi dan Sumberdaya Mineral Republik Indonesia Nomor 26 tahun 2018 tentang Pelaksanaan Kaidah Pertambangan yang Baik dan Pengawasan Pertambangan Mineral dan Batubara, dan Peraturan Daerah Provinsi Kalimantan Selatan Nomor 2 tahun 2017 tentang Rencana Perlindungan dan Pengelolaan Lingkungan Hidup Provinsi Kalimantan Selatan. Perumusan strategi pengelolaan lingkungan juga memperhatikan pada rancangan Rencana Tata Ruang Wilayah (RTRW) Kota Banjarbaru yang tertuang dalam Peraturan Daerah Nomor 13 tahun 2014 tentang 
Tabel 1. Parameter dan tolak ukur aspek penelitian

\begin{tabular}{|c|c|c|c|}
\hline Aspek & Parameter & Tolak Ukur & $\begin{array}{l}\text { Harkat/ } \\
\text { Skor }\end{array}$ \\
\hline \multirow[t]{15}{*}{ Abiotik } & $\begin{array}{l}\text { Lokasi } \\
\text { pertambangan } \\
\text { rakyat }\end{array}$ & $\begin{array}{l}\text { Tidak rusak, apabila lokasi berada di luar kawasan Cagar Alam, Suaka Margasatwa, } \\
\text { Taman Nasional, Taman Wisata Alam atau Hutan Raya } \\
\text { Sedang, lokasi berada di perbatasan kawasan Cagar Alam, Suaka Margasatwa, Taman } \\
\text { Nasional, Taman Wisata Alam atau Hutan Raya } \\
\text { Rusak, lokasi pertambangan berada di dalam kawasan konservasi }\end{array}$ & 3 \\
\hline & \multirow{2}{*}{$\begin{array}{l}\text { Metode } \\
\text { penambangan }\end{array}$} & Tidak rusak, bila menggunakan metode tertutup di seluruh lubang tambang & 3 \\
\hline & & $\begin{array}{l}\text { Sedang, bila menggunakan menggunakan metode tertutup hanya sebagian dari } \\
\text { seluruh lubang tambang } \\
\text { Rusak, bila menggunakan metode terbuka di seluruh lubang tambang }\end{array}$ & 2 \\
\hline & \multirow{2}{*}{$\begin{array}{l}\text { Reklamasi } \\
\text { lahan bekas } \\
\text { tambang }\end{array}$} & Tiddak rusak, bila melakukan penutupan lubang bekas tambang dan revegtasi segera & 3 \\
\hline & & $\begin{array}{l}\text { Sedang, bila melakukan penutupan lubang tetapi tidak segera dilakukan revegetasi } \\
\text { rusak, bila tidak melakukan penutupan bekas tambang }\end{array}$ & $\begin{array}{l}2 \\
1\end{array}$ \\
\hline & \multirow[t]{3}{*}{ Lahan terbuka } & $\begin{array}{l}\text { Tidak rusak, bila sudah dilakukan reklamasi di lahan terbuka }>80 \% \text { dan lubang } \\
\text { tambang sudah diperbaiki }\end{array}$ & 3 \\
\hline & & $\begin{array}{l}\text { Sedang, bila baru dilakukan reklamasi } 50 \%-80 \% \text { dan atau lubang tambang tidak di } \\
\text { tutup }\end{array}$ & 2 \\
\hline & & Rusak, bila rekalamasi dilakukan $<50 \%$ & 1 \\
\hline & \multirow{3}{*}{$\begin{array}{l}\text { Perlindungan } \\
\text { tanah pucuk }\end{array}$} & Tidak rusak, bila sudah dilakukan perlindungan $75 \%$ & 3 \\
\hline & & Sedang, bila ada perlindungan tanah pucuk $<75 \%$ & 2 \\
\hline & & Rusak, bila tidak ada perlindungan tanah pucuk & 1 \\
\hline & \multirow{3}{*}{$\begin{array}{l}\text { Hilangnya } \\
\text { jenis dan } \\
\text { jumlah } \\
\text { vegetasi }\end{array}$} & $\begin{array}{l}\text { Tidak rusak, bila jenis dan jumlah vegetasi sama atau meningkat dari sebelum } \\
\text { pertambangan }\end{array}$ & 3 \\
\hline & & Sedang, bila jenis dan jumlah vegetasi $50-100 \%$ dari seelum penambangan & 2 \\
\hline & & Rusak, bila jenis dan jumlah vegetasi kurang dari $50 \%$ dari sebelum penambangan & 1 \\
\hline & $\begin{array}{l}\text { Hilangnya } \\
\text { jenis fauna }\end{array}$ & $\begin{array}{l}\text { Tidak rusak, bila masih dijumpai jenis fauna terestrial yang dijumai sebelum } \\
\text { penambangan }\end{array}$ & 3 \\
\hline \multirow[t]{2}{*}{ Biotik } & terestrial & $\begin{array}{l}\text { Sedang, bila jarang dijumpai jenis fauna terestrial yang dijumpai sebelum } \\
\text { penambangan }\end{array}$ & 2 \\
\hline & & Rusak, bila tidak pernah dijumpai jenis fauna yang dijumpai sebelum penambangan & 1 \\
\hline \multirow[t]{15}{*}{ Kultural } & \multirow{3}{*}{$\begin{array}{l}\text { Perubahan } \\
\text { mata } \\
\text { pencaharian }\end{array}$} & $\begin{array}{l}\text { Tidak rusak, bila mata pencaharian masyarakat yang semula tidak terganggu atau } \\
\text { berubah }\end{array}$ & 3 \\
\hline & & $\begin{array}{l}\text { Sedang, bila mata pencaharian masyarakat terganggu tapi masyarakat memiliki } \\
\text { pekerjaan baru }\end{array}$ & 2 \\
\hline & & $\begin{array}{l}\text { Rusak, bila mata pencaharian masyarakat terganggu dan masyarakat tidak mendapat } \\
\text { pekerjaan baru }\end{array}$ & 1 \\
\hline & \multirow{3}{*}{$\begin{array}{l}\text { Perubahan } \\
\text { perilaku gaya } \\
\text { hidup }\end{array}$} & Tidak rusak, bila perilaku dan gaya hidup masyarakat tidak berubah & 3 \\
\hline & & $\begin{array}{l}\text { Sedang, bila perilaku masyarakat berubah namun tidak memengaruhi rasa } \\
\text { kekeluargaan di dalam masyarakat }\end{array}$ & 2 \\
\hline & & $\begin{array}{l}\text { Rusak, bila perilaku masyarakat berubah dan menghilangkan rasa kekeluargaan } \\
\text { dalam masyarakat }\end{array}$ & 1 \\
\hline & \multirow[t]{3}{*}{ Kesehatan } & $\begin{array}{l}\text { Tdak rusak, bila ksehatan penambang dan masyarakat sekitar lokasi tambang tidak } \\
\text { menurun }\end{array}$ & 3 \\
\hline & & Sedang, bila kesehatan terganggu tapi aktivitas tetap jalan & 2 \\
\hline & & Rusak, bila terdaat jenis penyakit akibat penambangan dan sulit disembuhkan & 1 \\
\hline & \multirow[t]{3}{*}{ Korban jiwa } & $\begin{array}{l}\text { Tidak rusak, bila kegiatan penambangan tidak pernah menimbulkan korban jiwa } \\
\text { sama sekali }\end{array}$ & 3 \\
\hline & & Sedang, bila ada koran jiwa akibat kegiatan tambang dalam rentang waktu $>1$ tahun & 2 \\
\hline & & Rusak bila banyak korban jiwa dalam rentang $<1$ tahun & 1 \\
\hline & \multirow[t]{3}{*}{ Konflik sosial } & $\begin{array}{l}\text { Tidak rusak, bila kegiatan penambangan tidak pernah menimbulkan konflik sosial } \\
\text { sama sekali }\end{array}$ & 3 \\
\hline & & $\begin{array}{l}\text { Sedang, bila terjadi konfli sosial akibat kegiatan penambangan dalam rentang waktu } \\
>1 \text { tahun }\end{array}$ & 2 \\
\hline & & Rusak, bila terdapat konflik sosial yang terjadi dalam waktu $<1$ tahun & 1 \\
\hline
\end{tabular}


Rencana Tata Ruang Wilayah Kota Banjarbaru (2014-2034). Metode yang digunakan dalam perumusan strategi pengelolaan lingkungan adalah metode matriks gabungan yang berisi perumusan pengelolaan dari tiap permasalahan lingkungan yang ditemui.

\section{HASIL DAN PEMBAHASAN}

Lokasi penambangan intan yang terdapat di Kecamatan Cempaka terletak di dua kelurahan, yakni Kelurahan Cempaka dan Kelurahan Sungai Tiung. Penambangan intan dilakukan secara bertahap, mulai dari persiapan sampai pada tahap akhir seperti yang ditunjukkan pada Gambar 1 (Djarani, 1990).

Tahapan menambang intan di atas merupakan tahapan menambang intan secara tradisional yang umum ditemukan di Kecamatan Cempaka, akan tetapi proses tersebut telah berubah dari waktu ke waktu sehingga mulai beralih dari tradisional menjadi semi-mekanik. Penggunaan mesin pompa dalam tahapan semi-mekanik menjadi dominan digunakan dengan tujuan hasil intan yang di dapat lebih banyak secara efektif dan efisien. Seiring berjalannya waktu, penggunaan dan pengembangan teknologi pada proses output penambangan berubah menjadi sebuah ketergantungan antara masyarakat terhadap sumberdaya alam (Reed dalam Kahhat et al, 2019). Perbedaan antara penambangan intan secara tradisional dan semi-mekanik disajikan pada Tabel 2 .

Penambangan intan yang bersifat semi-mekanik menggunakan mesin pompa untuk menyedot dan menyemprot air agar proses membuat lubang galian dalam mencari intan menjadi lebih cepat, akan tetapi perubahan ini membawa kerusakan terhadap lingkungan. Seperti kegiatan tambang-tambang rakyat lainnya, Adnan menyatakan
Tabel 2. Perbedaan penambangan intan secara tradisional dan semi-mekanik

\begin{tabular}{ll}
\hline Tradisional & Semi-mekanik \\
\hline $\begin{array}{l}\text { Menggunakan linggis, } \\
\text { dangkul, keranjang rotan }\end{array}$ & $\begin{array}{l}\text { Menggunakan mesin pompa } \\
\text { dan penyedot }\end{array}$ \\
$\begin{array}{l}\text { Dapat dilakukan } \\
\text { Kedalaman lubang 2-5 m }\end{array}$ & $\begin{array}{l}\text { Kedalaman lubang bisa } \\
\text { mencapai }>8 \mathrm{~m}\end{array}$ \\
$\begin{array}{l}\text { Tidak ada pemilahan } \\
\text { material }\end{array}$ & $\begin{array}{l}\text { Ada pemilahan material } \\
\text { (lumpur, kerikil, kerakal, } \\
\text { batuan) }\end{array}$ \\
$\begin{array}{l}\text { Sistem pembagian hasil } \\
\text { belum tentu ada }\end{array}$ & $\begin{array}{l}\text { Terdapat sistem pembagian } \\
\text { hasil }\end{array}$ \\
\hline
\end{tabular}

(Sumber: Djarani, 1990)

(dalam Wahyudi \& Slameto, 2017) indikasi adanya permasalahan umum seperti keterbatasan akses ekonomi dalam memilih alternatif mata pencaharian di bidang lain, tambang yang bersifat ilegal (Hilson et al., 2017), terjadinya degradasi lingkungan yang menyebabkan penurunan flora dan fauna (Cristesciu dalam Obeng et al., 2019), mengancam kesehatan dan keselamatan kerja penambang (Dawson dalam Laurentiu, 2016) serta menyebabkan kerusakan lingkungan fisik karena bersifat sporadic (Affum et al., 2016) juga ditemukan di tambang intan ini. Permasalahan lingkungan yang terjadi karena aktivitas penambangan intan di Kecamatan Cempaka juga dilatarbelakangi oleh gagalnya regulasi daerah yang terkendala payung hukum. Peraturan Daerah Nomor 5 tahun 2002 tentang Pengelolaan Pertambangan Rakyat Bahan Galian Strategis dan Vital

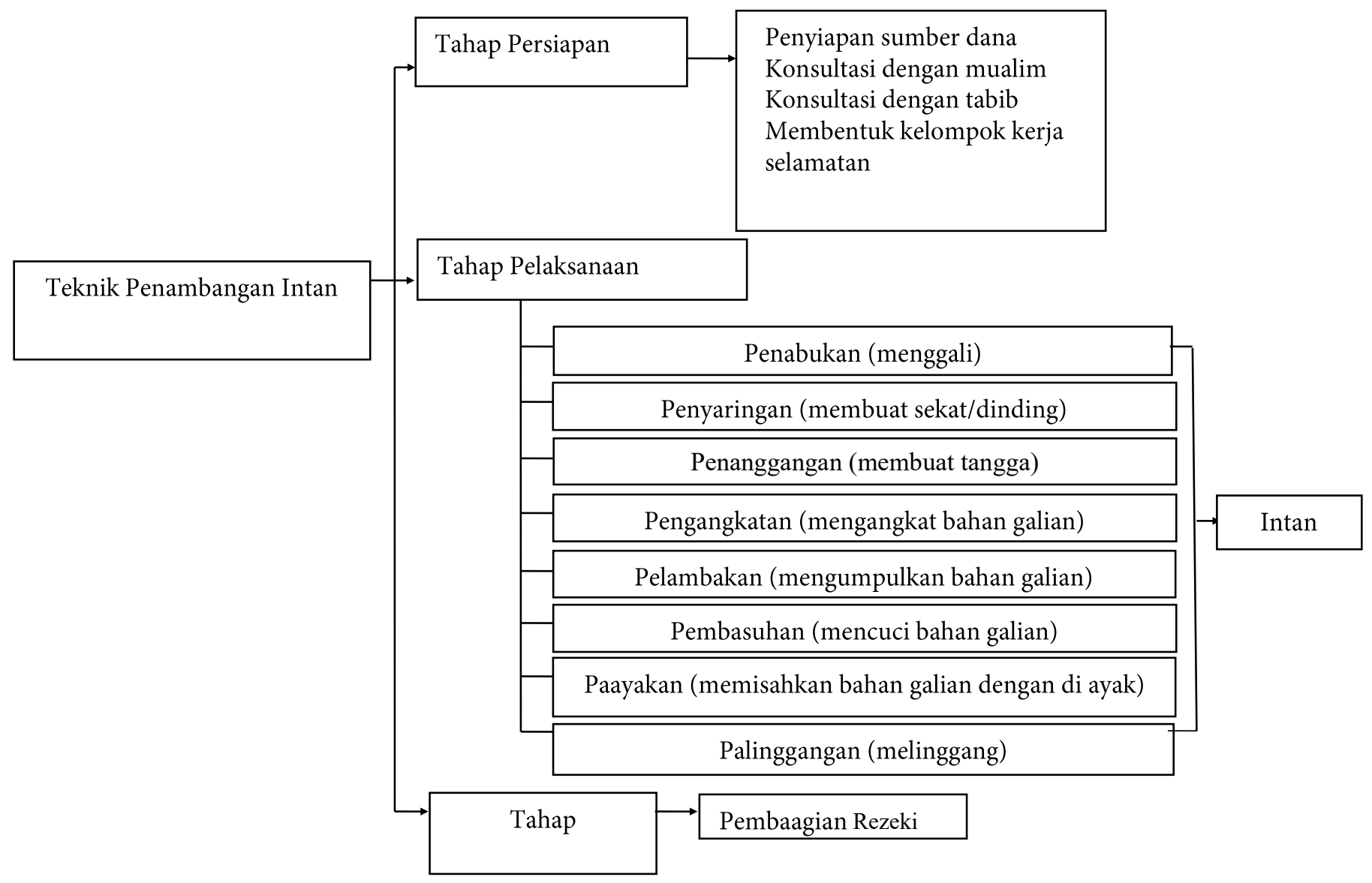

Gambar 1. Tahapan Dalam Menambang Intan 


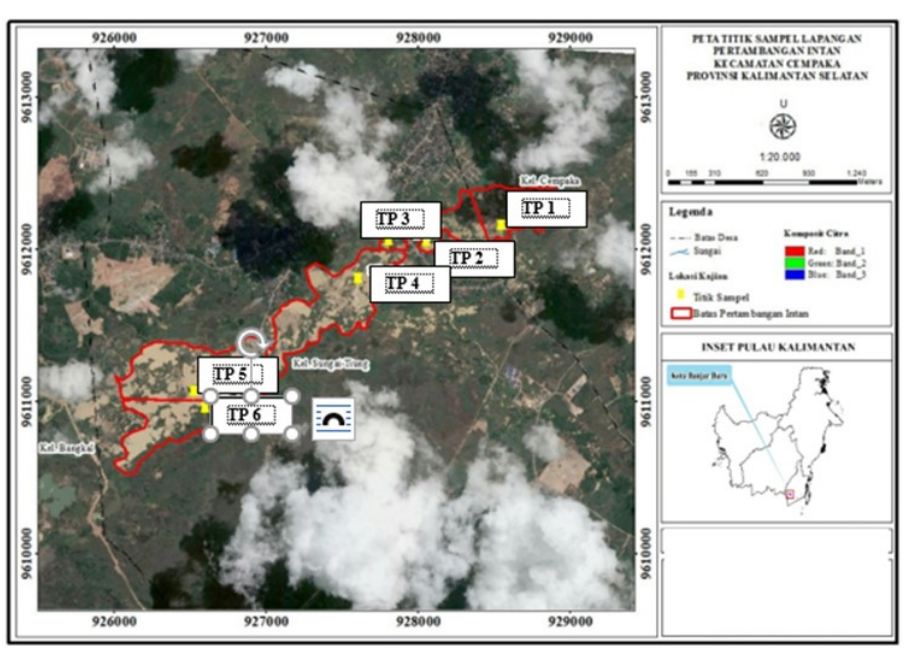

Gambar 2. Penentuan Titik Pengamatan (Sumber: Citra Google Earth 26 April 2017)

(Golongan B \& C) pernah diberlakukan, namun setahun setelah Perda ini diberlakukan dicabut berdasarkan instruksi dari Menteri Dalam Negeri. Akibatnya, kegiatan tambang ini sangat sulit ditertibkan oleh pemerintah daerah karena tidak adanya payung hukum dan menyebabkan semakin rusaknya lingkungan sekitar (Yana, 2010).

Jumlah pertambangan intan yang ditemui di lapangan pada dua kelurahan tidak sama, penambangan intan yang dijumpai di lapangan lebih banyak berada di Kelurahan Sungai Tiung. Kondisi penambangan intan yang tersebar dimana-mana, melatarbelakangi ditentukannya titik pengamatan. Penentuan dilakukan menggunakan grid pada peta, sehingga membentuk segmen-segmen yang kemudian ditentukan secara purposive titik yang ada pada tiap segmen yang mampu mewakili seluruh kondisi penambangan. Berdasarkan segmen yang telah dibagi, maka penentuan titik pengamatan yang disingkat menjadi TP pada peta, berdasarkan kondisi di lapangan menunjukkan bahwa terdapat enam titik pengamatan seperti pada Gambar 2.

\section{Identifikasi jenis kerusakan lingkungan}

Hasil pengharkatan menunjukkan bahwa aspek abiotik adalah aspek yang paling mengalami kerusakan karena penambangan intan dengan skor 3 atau dinyatakan "rusak" pada tiap parameternya. Perolehan hasil pada tiap kelas di masing-masing aspek memiliki perbedaan terkait seberapa besar kerusakan yang terjadi, sehingga dilakukan perhitungan kembali untuk memeroleh persentase yang menunjukkan aspek mana yang mengalami kerusakan paling besar di tiap kelasnya. Berdasarkan hasil perhitugan menunjukkan bahwa aspek abiotik adalah aspek dengan persentase kerusakan tertinggi. Persentase jenis kerusakan lingkungan dilakukan melalui tahapan perhitungan melalui persamaan 2 dan hasil perhitungan untuk persentase aspek ditunjukkan pada Tabel 3.

Berdasarkan hasil pengamatan di lapangan, pada tahap identifikasi jenis kerusakan lingkungan dapat diketahui bahwa terdapat kesesuaian antara acuan dari parameter yang digunakan dengan jenis kerusakan yang ada di lokasi penambangan intan. Selain itu, aspek abiotik adalah aspek yang teridentifikasi mengalami kerusakan paling tinggi dengan jumlah skor 3 atau "Rusak" pada empat dari lima parameter yang ada.

\section{Analisis tingkat kerusakan lingkungan}

Pada umumnya, kegiatan pertambangan memunculkan dua sisi yang sangat berlawanan, yakni dapat bersifat menguntungkan ketika pertambangan menghasilkan income dan pertumbuhan ekonomi dan menjadi sangat merugikan ketika pertambangan membahayakan kesehatan, keselamatan dan memunculkan kerusakan pada lingkungan (Mancini \& Serenella, 2018). Berdasarkan hasil perhitungan kelas interval yang telah dilakukan, diketahui tingkat kerusakan sebagai kategori untuk deskripsi pada seluruh titik pengamatan diperoleh hasil pada Tabel 4 .

Dari kelas interval pada Tabel 4, maka dapat diperoleh bahwa dari semua titik pengamatan, tidak ada titik pengamatan yang termasuk dalam kategori tingkat kerusakan ringan, sehingga tingkat kerusakan yang ada di seluruh titik pengamatan termasuk dalam kategori tingkat kerusakan sedang dan tingkat kerusakan berat. Keseluruhan titik pengamatan yang menempati kategori sedang berjumlah lima titik, dan hanya satu titik yang menempati kategori tingkat kerusakan berat. Sebaran tingkat kerusakan lingkungan untuk tiap titik pengamatan ditunjukkan pada Tabel 5.

Dari hasil analisis tingkat kerusakan, didapat bahwa titik pengamatan 4 adalah titik pengamatan yang menjadi titik dengan tingkat kerusakan lingkungan berat diantara titik pengamatan yang lainnya seperti yang ditunjukkan pada Gambar 3.

Titik pengamatan 4 menjadi titik dengan tingkat kerusakan berat dikarenakan titik ini merupakan lokasi penambangan yang paling terlihat ketika memasuki area tambang, walaupun dari Gambar 3 tidak menunjukkan bahwa titik pengamatan ini berada dekat dengan jalan utama, namun keberadaan lubang tambang pada titik ini merupakan lubang yang paling besar bahkan terlihat seperti danau ketika memasuki musim penghujan sehingga paling dominan menandakan bahwa titik pengamatan 4 ini adalah titik yang paling mudah teridentifikasi. Titik pengamatan 4 menjadi

Tabel 4. Kelas interval kerusakan lingkungan

\begin{tabular}{ccc}
\hline Kelas & $\begin{array}{c}\text { Deskripsi Kelas } \\
\text { Interval }\end{array}$ & Harkat/Skor \\
\hline I & Kerusakan Ringan & $12-19$ \\
II & Kerusakan Sedang & $20-27$ \\
III & Kerusakan Berat & $28-35$ \\
\hline
\end{tabular}

Sumber: Pengolahan Data, 2020

Tabel 5. Sebaran Tingkat Kerusakan Lingkungan pada Lokasi Penelitian

\begin{tabular}{|c|c|c|}
\hline Tingkat Kerusakan & Lokasi & Skor \\
\hline \multirow{4}{*}{ Ringan } & - & - \\
\hline & Titik Pengamatan 1 & 24 \\
\hline & Titik Pengamatan 2 & 24 \\
\hline & Titik Pengamatan 3 & 27 \\
\hline \multirow[t]{2}{*}{ Sedang } & Titik Pengamatan 5 & 26 \\
\hline & Titik Pengamatan 6 & 25 \\
\hline Berat & Titik Pengamatan 4 & 28 \\
\hline
\end{tabular}

(Sumber: Pengolahan Data, 2020) 


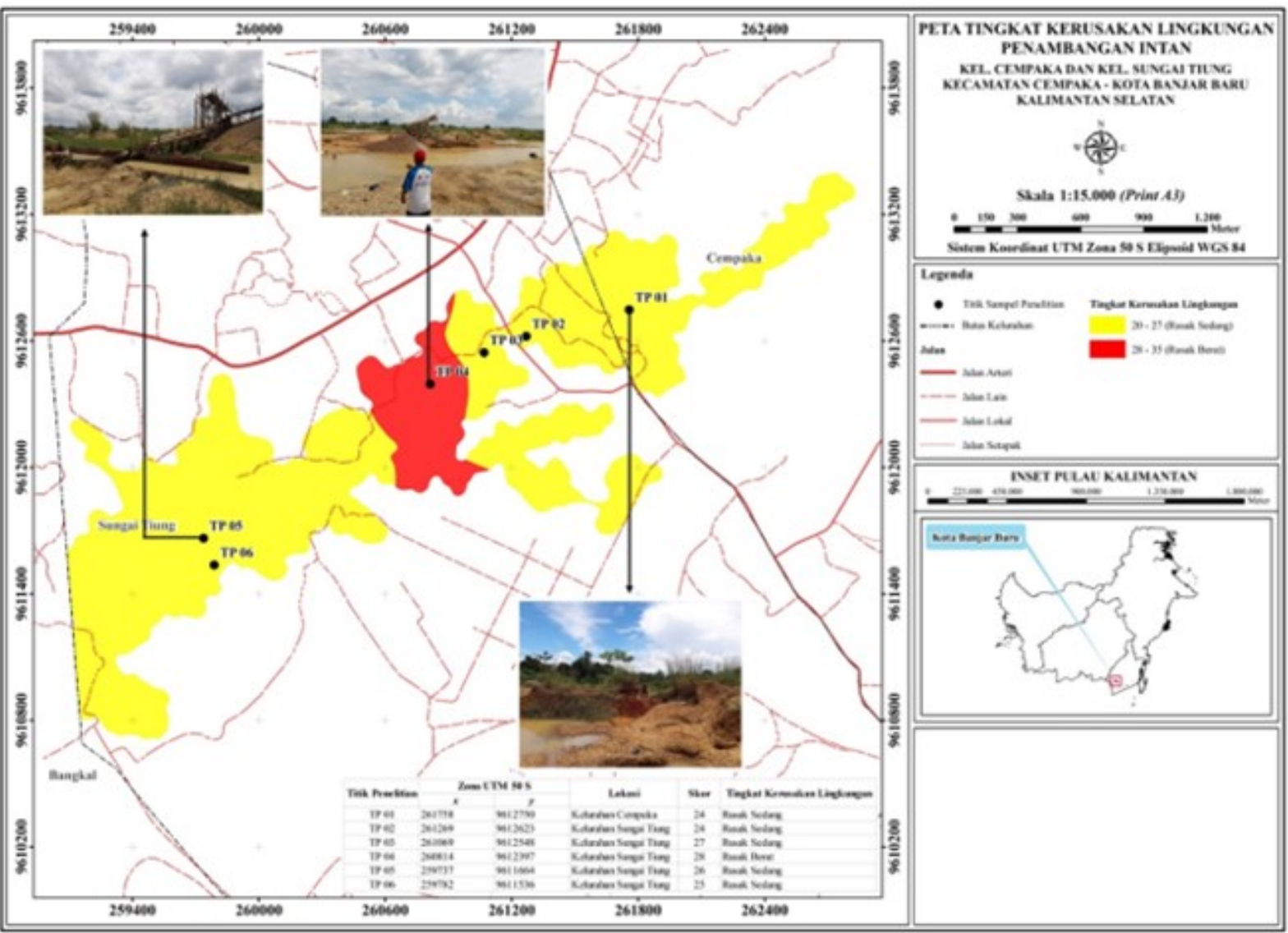

Gambar 3. Tingkat Kerusakan Lingkungan

lokasi utama para penambang untuk memeroleh intan, yang menyebabkan kerusakan pada titik ini paling berat dibandingkan dengan titik lainnya. Pada titik ini pula intan Trisakti pada tahun 1965 dengan ukuran 166,72 krat, intan Galuh Badu pada tahun 1967 dengan ukuran 26,50 krat dan pada tahun 1969 ditemukan intan Galuh Cempaka dan Galuh Bulan dengan ukuran 27,5 krat (Sukandarrumidi, 1998). Bahkan intan Trisakti yang ditemukan pada tahun 1965 merupakan penemuan intan yang paling menghebohkan karena ukurannya krat nya yang sangat besar dan hingga kini keberadaannya menjadi misteri karena keberadaannya yang tidak tahu dimana setelah pertama kali ditemukan langsung di bawa ke Jakarta sebab dianggap sebagai penemuan yang sangat bernilai. Penamaan Trisakti sendiri diberikan oleh Presiden Ir. Soekarno kala itu. Menurut informan, apabila intan pernah ditemukan pada suatu lokasi, maka penambang berharap bahwa akan ada intan lainnya yang dapat ditemukan, sehingga setelah kurun waktu yang lama sejak ditemukannya intan-intan tersebut, titik pengamatan 4 masih menjadi lokasi yang paling tinggi aktivitas pertambangannya sampai sekarang dan menyebabkan kerusakan lingkungan yang paling berat diantara titik pengamatan 1, 2, 3, 5 dan 6 . Titik pengamatan 2 dan 3 termasuk dalam kategori tingkat kerusakan sedang juga mengalami kerusakan yang serupa dengan titik pengamatan 4 , bedanya lubang galian pada titik pengamatan 4 dapat mencapai ukuran dengan dalam $>15$ meter dan diameternya $>20$ meter. Dalamnya lubang galian pada titik pengamatan 4 juga sering menimbulkan korban jiwa yakni 5 penambang tewas pada April 2019 (www.kalselpos.com, 2019) dan 1 penambang juga tewas pada bulan Juli (www.kompas.com, 2019), karena terjadi longsoran tanah galian pada bagian atas lubang, sehingga skoring untuk aspek kerusakan kultural pada parameter korban jiwa di titik pengamatan 4 adalah 3 . Ketika memasuki musim hujan, lubang galian ini akan berubah drastis seperti danau yang dipenuhi oleh air sampai permukaan atas lubang galian. Kedalaman lubang galian yang mencapai 20 meter memperlihatkan kondisi perubahan yang sangat drastis pada lubang galian ketika musim kemarau dan musim hujan. Kondisi perubahan tersebut dapat dilihat pada Gambar 4.

Bansah et.al. (2018) menjelaskan dalam penelitiannya bahwa munculnya tambang-tambang ilegal yang berskala kecil dapat disebabkan oleh faktor regulasi dan susahnya mengurus izin tambang, sehingga bagi penambang dengan kompetensi pendidikan yang rendah cenderung merasa malas untuk mengurusnya dan lebih memilih tetap bertahan pada status ilegal di tambang tersebut. Kondisi serupa juga terjadi pada tambang intan di Kecamatan Cempaka, kendala -kendala tersebut juga turut menjadi faktor mengapa sampai sekarang kerusakan lingkungan pada area penambangan intan terus terjadi. Penambangan intan yang tergolong sebagai pertambangan rakyat merupakan jenis pertambangan yang tidak pasti dan keberlanjutannya patut dipertanyakan. Di sisi lain jenis tambang seperti ini memang dijadikan sebagai tempat mata pencaharian pokok oleh masyarakat sekitar, namun seiring berjalannya kerusakan lingkungan yang ada juga akan semakin diperparah oleh adanya aktivitas tersebut. Engwicth (2018) menyatakan dalam penelitiannya bahwa keberadaan pertambangan rakyat perlu diperhatikan keberlanjutannya oleh seluruh pihak. Tambang intan di Kecamatan Cempaka juga seharusnya mendapatkan perhatian terutama dari pihak pemerintah agar kejelasan terkait status lokasi dan mata pencaharian para penambang menjadi lebih pasti, terlebih 
lagi kerusakan lingkungan yang disebabkan oleh penggunaan mesin dalam menambang intan juga patut menjadi perhatian lain oleh pemerintah yang juga menyangkut keberlanjutan sektor ini. Penggunaan mesin ketika menambang sangat tidak ramah lingkungan dan cepat merusak tanah, sehingga potensi kerusakan yang dihasilkan akan lebih besar dibandingkan dengan menambang tanpa menggunakan mesin seperti pada Gambar 5.

Pertambangan intan telah menjadi komoditas utama bagi masyarakat sekitar dalam memenuhi kebutuhan hidupnya. Ketergantungan pada ketersediaan jumlah mineral mendorong mereka untuk terus beraktivitas dan melakukan mengandalkan pertambangan sebagai tumpuan hidupnya (Carney \& Gushulak, 2016). Para penambang intan dengan keterbatasannya juga mengalami ketergantungan terhadap intan yang menjadi hasil tambang pokok, namun kini keberadaannya juga sudah sangat sulit untuk ditambang. Interpretasi terhadap para penambang rakyat perlu di lihat dari sudut pandang "kasino ekonomi" berupa "keberuntungan" atau "anugerah", seperti studi kasus yang terdapat di Sierra Leone, penambang rakyat sangat kecil kemungkinan dapat beruntung mendapatkan komoditasnya dikarenakan cenderung beradu nasib secara tidak pasti (D’Angelo, 2015). Semakin tahun, jumlah penambang semakin berkurang dikarenakan intan yang ditambang sudah semakin sulit ditemukan. Berkurangnya jumlah penambang ini terjadi karena mereka mencoba pekerjaan lain seperti menggali sumur maupun membantu menggarap kebun dan sawah orang. Selain itu, keberadaan intan yang semakin sedikit, menyebabkan penambang juga beralih menjual kerikil dan pasir dari hasil menambang, sehingga komoditas Bahan Galian Golongan C menjadi alternatif lain ketika intan sangat jarang dijumpai. Gambaran kondisi ekonomi para penambang juga tidak pernah mengalami peningkatan sejak akhir tahun 1980 ketika penambangan intan sedang gencargencarnya dilakukan, sehingga dapat dikatakan bahwa penambang masih belum sejahtera. Padahal kerusakan lingkungan yang ditimbulkan dari kegiatan pertambangan ini sudah sangat mengkhawatirkan, namun ternyata tinggi intensitas pertambangan yang menyebabkan kerusakan lingkungan tidak berjalan seiringan dengan kenaikan pada sisi ekonomi.

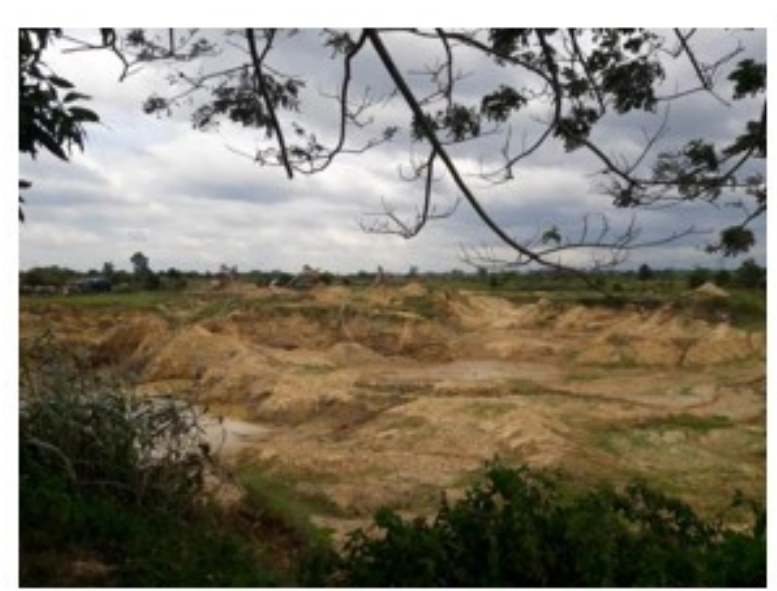

(a)

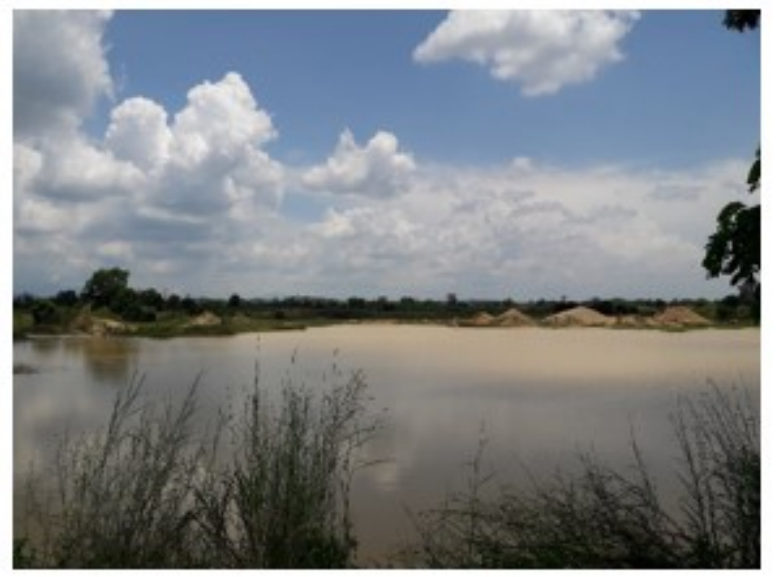

(b)

Gambar 4 Kondisi lubang galian pada TP 4 (a) Kondisi lubang galian pada TP 4 ketika musim kemarau (b) Perubahan secara drastis lubang galian yang penuh tertutupi oleh air saat di musim penghujan

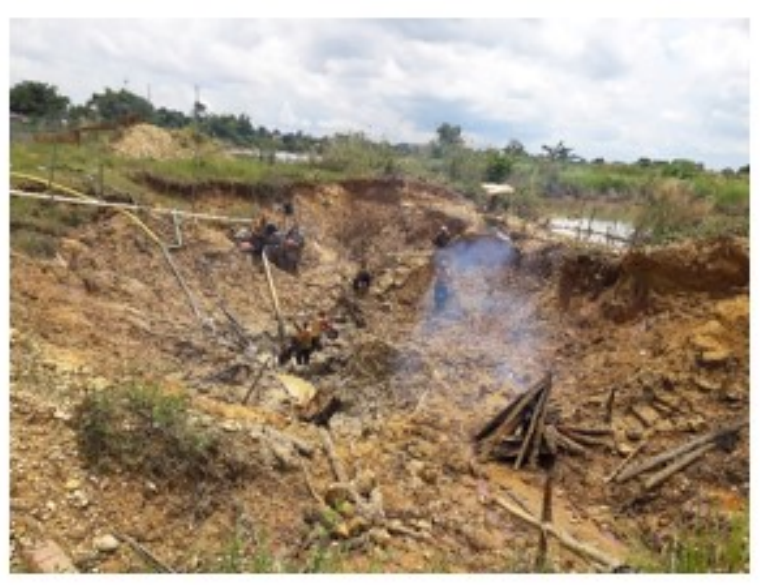

(a)

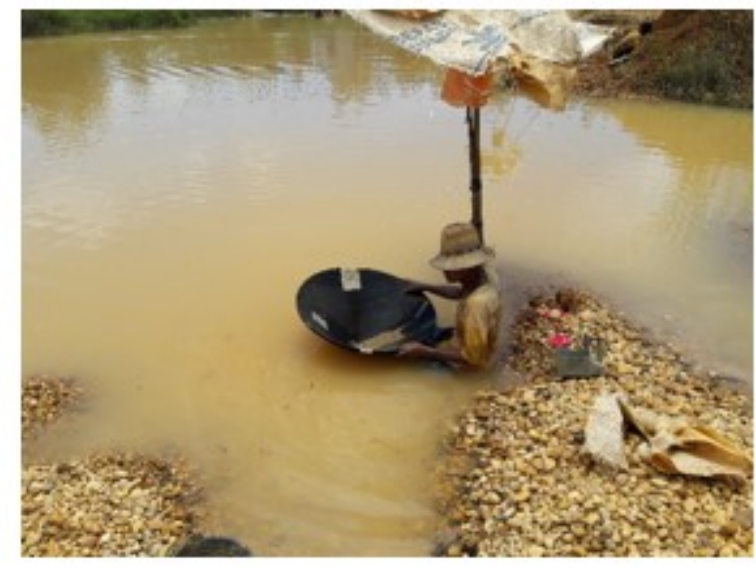

(b)

Gambar 5 Perbedaan menambang intan (a) Penambangan intan menggunakan mesin yang lebih semimekanik cenderung lebih meyebabkan kerusakan pada lingkungan (b) Proses penambang sedang melakukan "palinggangan" atau "melinggang" menggunakaan alat yang bernama linggang. Proses ini merupakan satusatunya tahapan dari dulu hingga sekarang yang sifat ke tradisionalnnya masih umum ditemukan dalam kegiatan menambang intan saat ini di Kecamatan Cempaka. (koordinat -3.501062 S, 114.855458 E) 


\section{Perumusan Strategi Pengelolaan Lingkungan}

Perumusan strategi pengelolaan lingkungan dibuat sebagai bentuk alternatif dan bentuk referensi permasalahan lingkungan yang terjadi pada penambangan intan. Perumusan strategi pengelolaan lingkungan menggunakan metode matriks gabungan dan berkonsep pada payung hukum serta peraturan daerah setempat agar dapat menyesuaikan arahan dan rekomendasi yang lebih tepat. Undang-Undang Rencana Perlindungan dan Pengelolaan Lingkungan Hidup No 32 Tahun 2009, Peraturan Pemerintah Nomor 23 Tahun 2010 tentang Pelaksanaan Kegiatan Usaha Pertambangan Mineral dan Batubara, Peraturan Menteri ESDM Nomor 26 Tahun 2018, Peraturan Daerah Kalimantan Selatan Nomor 2 Tahun 2017 mengenai Rencana Pemanfaatan dan Pencadangan SDA dan Peraturan Daerah 13 Tahun 2014 tentang RTRW Kota Banjarbaru (2014-2034) menjadi konsep perumusan strategi pengelolaan lingkungan yang digunakan. Beberapa hasil perumusan menunjukkan bahwa beberapa rekomendasi di bawah ini adalah rekomendasi yang dirasa paling sesuai dengan kondisi penambangan intan yang telah mengalami kerusakan.

1. Menutup kawasan tambang dan mereklamasi lubang bekas galian.Penutupan kawasan tambang merupakan rekomendasi dan arahan yang sesuai untuk mengatasi kerusakan lingkungan. Selain itu, potensi intan yang tidak pernah bisa diprediksi saat ini dapat juga menjadi pertimbangan paling penting untuk menutup kawasan pertambangan sehingga kerusakan lingkungan tidak lagi terjadi dan semakin parah. Selain itu, status ilegal pada kawasan tambang tersebut juga menjadi pertimbangan, karena seharusnya penambangan yang baik haruslah memenuhi syarat dan perizinan seperti yang telah diatur dalam PP Nomor 23 Tahun 2010 tentang Pelaksanaan Kegiatan Usaha Pertambangan Mineral dan Batubara berupa; (1) persyaratan administrasi (2) persyaratan teknis (3) persyaratan lingkungan dan finansial dan (4) kegiatan pertambangan haruslah mengantongi Izin Usaha Pertambangan (IUP), Izin Pertambangan Rakyat (IPR) dan Izin Usaha Pertambangan Khusus (IUPK), sedangkan pada lokasi penelitian yang juga merupakan kawasan penambangan intan tidak memenuhi seluruh persyaratan tersebut. Reklamasi lubang bekas galian tambang juga perlu dilakukan untuk memperbaiki kondisi lingkungan meskipun sangat susah untuk mengembalikan kembali fungsi dan kualitas lingkungan seperti yang sebelumnya. Arahan ini apabila diterapkan akan menjadi langkah untuk mencapai tujuan yang tertuang dalam Undang-Undang Rencana Perlindungan dan Pengelolaan Lingkungan Hidup Nomor 32 tahun 2009.

2. Melakukan perubahan mata pencaharian bagi para penambang. Pendekatan ekonomi kepada penambang menjadi alternatif yang bisa digunakan untuk menerapkan arahan ini. Merubah mata pencaharian berarti merubah seluruh kehidupan penambang, oleh sebab itu perlu sosialisasi dan pendampingan secara bertahap dengan diimbangi oleh pembekalan kemampuan bagi penambang. Pelaksanaan arahan ini memerlukan koordinasi yang sangat baik antara pemerintah dan masyarakat maupun lembaga kursus yang berhubungan dan terkait dengan arahan ini.

3. Menerapkan konsep good mining practice.Konsep good mining practice merupakan konsep pertambangan yang sesuai dengan kaidah seperti yang tertuang dalam Ayat 1 Pasal 3 Peraturan Menteri ESDM Nomor 26 Tahun 2018 yang secara garis besar memuat tentang teknis pertambangan, konservasi, keselamatan, serta pengelolaan lingkungan. Arahan ini menjadi salah satu strategi pengelolaan lingkungan apabila arahan pada poin sebelumnya tidak berhasil diterapkan dan penambang lebih memilih untuk tetap beraktivitas seperti biasanya. Dengan diterapkannya konsep ini, maka harapannya kedepan penambang mampu mengurangi risiko kerusakan lingkungan dan juga keselamatan dengan mengikuti kaidah yang ada. Selain itu apabila arahan ini berhasil dilaksanakan maka akan mencapai tujuan yang termuat dalam Peraturan Darah Kalimantan Selatan Nomor 2 tahun 2017 mengenai rencana pemanfaatan dan pencadangan SDA, pemeliharaan dan perlindungan kualitas lingkungan serta pengendalian terhadap pelestarian SDA.

4. Menambah fungsi kawasan menjadi tujuan pariwisata. Menambah fungi kawasan menjadi tujuan pariwisata adalah arahan yang dirasa paling sesuai untuk pengelolaan lingkungan. Seperti yang terdapat dalam Peraturan Daerah Kota Banjarbaru Nomor 13 Tahun 2014 tentang RTRW Kota Banjarbaru (2014-2034) telah disebutkan bahwa kawasan penambangan intan akan diperuntukkan sebagai tujuan lokasi wisata berbasis kebudayaan. Dengan dijadikannya kawasan penambangan menjadi tujuan wisata, para penambang dapat beralih mata pencaharian pada sektor wisata dan kerusakan lingkungan akan semakin terminimalisir seperti yang tercantum pada Masterplan Kawasan Geowisata Pumpung Cempaka oleh Dinas Pemuda dan Olahraga Kebudayaan dan Pariwisata Kota Banjarbaru tahun 2019.

\section{KESIMPULAN}

Jenis kerusakan lingkungan yang terjadi akibat aktivitas pertambangan intan merupakan kerusakan yang mencakup seluruh aspek abiotik, biotik dan kultural. Analisis tingkat kerusakan menunjukkan bahwa titik pengamatan 4 di Kelurahan Sungai Tiung menjadi titik dengan tingkat kerusakan yang berat. Kerusakan terberat terjadi pada aspek abiotik yang terdiri dari beberapa unsur parameter seperti kerusakan tanah berupa bekas lubang galian, lahan terbuka, tidak ada perlindungan tanah pucuk dan reklamasi. Upaya pengelolaan berupa penutupan lahan tambang, melakukan reklamasi, menerapkan konsep good mining practice, dan mengalihfungsikan lokasi pertambangan menjadi tujuan wisata merupakan strategi yang sesuai untuk kerusakan lingkungan yang ada. Potensi kerusakan lingkungan pada lokasi pertambangan akan selalu ada, bahkan pada jenis pertambangan skala kecil. Kegiatan pertambangan yang memerhatikan pada keberlanjutan dapat meminimalisir kerusakan yang akan terjadi. Koordinasi yang baik antara pemerintah dan masyarakat serta penerapan kebijakan dan regulasi yang tepat dapat menjadi langkah utama dalam mengatasi permasalahan kerusakan lingkungan karena kegiatan pertambangan.

\section{UCAPAN TERIMAKASIH}

Ucapan terimakasih penulis sampaikan kepada Putra Y. Ariesandi, S. Sos., M. M sebagai Lurah Kelurahan Sungai Tiung, Aris Munandar, S. Pi selaku sekretaris Kelurahan 
Cempaka, Lilik Indahyati, S. Sos selaku Kasie Ekobang Kecamatan Cempaka, Rusmilawati, S. Hut., M.S selaku Kasi Pemantauan, Pengawasan dan Kajian Dampak Lingkungan Dinas Lingkungan Hidup Kota Banjarbaru, Wida Dewayana, S. E selaku Kasi Pembangunan dan Pengembangan Destinasi Wisata Dinas Pemuda Olahraga Budaya dan Pariwisata Kota Banjarbaru, Erwin, S. T selaku Kepala Bidang Fisik Prasarana Pembina TK.I, M. Noor S. Pd selaku Ketua RW.011 sekaligus Ketua Forum Perkumpulan RT dan RW se-Kecamatan Cempaka, Wailiani selaku Ketua Forum Perkumpulan RT \& RW se Kelurahan Sungai Tiung dan Ryoto Ketua RT.031 Sungai Tiung.

\section{DAFTAR PUSTAKA}

Affum, A. 0., Dede, S. O., Nyarko, B. J., Acquaah, S. O., KwaansaAnsah, E. E., Darko, G., Fianko, J. R. (2016). Influence of SmallScale Mining and Toxic Element Concentration in Bonsa River Ghana: A Potential Risk to Water Quality and Public Health. Environmental Earth Science, 75(2), 178. doi: 10.007/s12665-155000-8: 2-17

Arikunto, Suharsimi. (2013). Prosedur Penelitian Suatu Pendekatan Praktek, Jakarta. Penerbit Rineka Cipta.

Azkia, Laila. (2018). Analisis Sosiologi Ekonomi Pada Tambang Rakyat (Kajian terhadap Kegiatan Ekonomi dalam Tambang Rakyar Intan di Cempaka, Banjarbaru, Kalimantan Selatan). Sosioglobal:Jurnal Pemikiran dan Penelitian Sosiologi 3(1): 6069.

Bansah, K. J., Dupey, Dumakor, N.K., Kansake, B. A., Assan, E., Bekui, P. (2018). Socioeconomic and Environmental Assessment of Informal Artisanal Mining and Small-scale Mining in Ghana. Journal of Clear Production (202): 465-475.

Carney, J.G \& Gushulak, B.D. (2016). A Review of Research on Health Outcomes, for Workers, Home and Host Communities of Population Mobility Associated with Extractive Industries. $J$. Immigr. Minority Health 18(3): 673-686

D’Angelo, L. (2015). "Diamond mining is Chain": Luck, Blessing and Gambling in Sierra Leone's Artisanal Mines. Crit. Afr. Stud 7(3); 243-261.

Dina. (2019, 09 April) Lima pendulang intan cempaka tertimbun longsor. Kalselpos. Diakses tanggal 23 Februari 2021 dari https://kalselpos.com/2019/04/09/lima-pendulang-intancempaka-tertimbun-longsor/

Dinas Penanaman Modal dan Pelayanan Terpadu Satu Pintu. (2018). Potensi Pertambangan. Diakses tanggal 19 September 2019 dari https://dpmptsp.kalselprov.go.id/potensipertambangan $/ \mathrm{html}$

Djarani. E. M. (1998). Mendulang Intan di Martapura. Perpustakaan Provinsi. Kalimantan Selatan. Arsip Deposit.

Engwicth, Nina. (2018). "It can Lift Someone from Poverty": Imagined Futures in the Sierra-Leonean Diamond Market. The Extractive Industries and Society 5: 260-266.

Hasnia. (2018). Kajian Kerusakan Lingkungan Akibat Penambangan Bijih Nikel di Kecamatan Bahodopi Kabupaten Morowali Provinsi Sulawesi Tengah. Tesis. Yogyakarta. Sekolah Pascasarjana. Universitas Gadjah Mada

Hilson, G., Hilson, A., Maconachie, R., McQuilken, J. (2017). Artisanal and Small-scale Mininh (ASM) in Sub-saharan Africa: Re-Conceptualizing Formalization and "Illegal" Activity. Geoforum 83, 80-90. doi: 10.1016/j.geoforum.2017.05.004

https://regional.kompas.com/read/2019/07/24/07000001/lagilongsor-di-pendulangan-intan-kalsel-satu-penambang-tewastertimbun. Diakses tanggal 23 Februari 2021.

Kahhat, Ramzy., Parodi, Eduardo., Gallegos-Larea, Gustavo., Mesta, Carlos., Rowe-Vázques, Ian. (2019). Environmental Impacts of the Life Cycle of Alluvial Gold Mining in the Peruvian Amazon Rainforest. Science of the Total Environment 662(2019), 940951. doi: 10.1016/j.scitotenv.2019.01.246

Kementrian Lingkungan Hidup dan Kehutanan. (2015). Buku I
Kerusakan Lahan Akses Terbuka Akibat Tambang Rakyat Tahun 2015. Jakarta.

Laurentiu, G. M., Cristina, F. M., Loreta, A. C. (2016). The Assessment of Social and Economic Impacts Associated to an Abandoned Mining Site. Case Study: Ciudanovita (Romania). Procedi Environmental Science 32(2016), 420-430. doi: 10.1016/ j.proenv.2016.03.048.

Mancini, Lucia and Sala, Serenella. (2018). Social Impact Assessment in the Mining Sector: Review and Comparison Indicators Frameworks. Resources Policy 57(2018), 98-111. doi: 10.1016/j/resourcepol.2018.02.002.

Menteri Dalam Negeri. (1998). Keputusan Bersama Nomor: $151 \mathrm{~A}$ Tahun 1998. Jakarta.

Menteri Koperasi, Pengusaha Kecil dan Menengah. (1998). Keputusan Bersama Nomor: 23/SKB/M/XII/1998. Jakarta

Menteri Pertambangan dan Energi. (1998). Keputusan Bersama Nomor: 2002.K/20/MPE/1998. Jakarta.

Obeng, Elizabeth, Asantewaa., Oduro, Kwame, Antwi., Obiri, Beatrice, Darko., Abukari, Haruna., Guuroh, reginald, Tang., Djagbletey, Gloria, Djaney., Korang, Joseph, Appiah., Appiah, Mark. (2019). Impact of Illegal Mining Activities on Forest Ecosystem Service: Local Communities' Attitude and Willingnes to Participate in Restoration Activities in Ghana. Heliyon (5), 1-11. doi: 10.1016/j.heliyon.2019.e02617.

Owusu, Obed., Bansah, Kenneth., Joseph, Mensah., Albert, Kobina (2019). "Small in Size, but Big in Impact": Socio-environmental Reform of Sustainable Artisanal and Small Scale-mining. Journal of Sustainable Mining 18(2019), 38-44. doi: 10.1016/ j.jsm.2019.02.001

Pemerintah Daerah Kota Banjarbaru.(2002). Peraturan Daerah Nomor 5 Tahun 2002 tentang Pengelolaan Pertambangan Rakyat Bahan Galian Strategis dan Vital (Golongan $B \& C)$.Banjarbaru.

Pemerintah Daerah Kota Banjarbaru.(2014). Peraturan Daerah Nomor 13 tahun 2014 tentang Rencana Tata Ruang Wilayah Kota Banjarbaru (2014-2034). Banjarbaru.

Pemerintah Daerah Provinsi. (2017). Peraturan Daerah Provinsi Kalimantan Selatan Nomor 2 Tahun 2017 tentang Rencana Perlindungan dan Pengelolaan Lingkungan Hidup Provinsi Kalimantan Selatan. Kalimantan Selatan.

Pemerintah Indonesia. (2009). Undang-Undang Republik Indonesia Nomor 32 Tahun 2009 tentang Perlindungan dan Pengelolaan Lingkungan Hidup. Jakarta.

Pemerintah Indonesia. (2010). Peraturan Pemerintah Nomor 23 tahun 2010 tentang Pelaksanaan Kegiatan Usaha Pertambangan Mineral dan Batubara. Jakarta.

Pemerintah Indonesia. (2018). Peraturan Menteri Energi dan Sumberdaya Mineral Republik Indonesia Nomor 26 Tahun 2018 tentang Pelaksanaan Kaidah Pertambangan yang Baik dan Pengawasan Pertambangan Mineral dan Batubara. Jakarta.

Sukandarrumidi. (1998). Bahan Galian Industri. Yogyakarta. Gadjah Mada University Press.

Wahyudi, Erwan dan Slameto. (2017). Dampak Sosial Penambangan Emas Tanpa Izin (PETI) tergadap Usaha Tani di Kabupaten Merangin Provinsi Jambi. Paper dipresentasikan pada Seminar Nasional Agroinovasi Spesifik Lokasi Untuk Ketahanan Pangan Pada Era Masyarakat ASEAN. 2017.

White, L.T., Graham, I., Tanner, D., Hall, R., Armstrong, R., Yaxley, G., Barron, L., Spencer, L., Van Leuween, T.M. (2016). The Provenance of Borneo's Enigmatic Alluvial Diamonds: a Case Study From Cempaka, SE Kalimantan. Gondwana Research (2016), 1-22. doi: 10.1016/j/gr.2015.12.007.

Yana, Agus. (2010). Praktik Pertambangan Intan dan Faktor-faktor yang Memengaruhi Alih Fungsi Lahan Sawah Menjadi Lahan Pertambangan Intan (Studi Kasus di Kelurahan Sungai Tiung, Kota Banjarbaru). Tesis. Bappenas. 